UDC $669.14 .018 .23: 669.15^{\prime} 891-194.2: 620.192 .45$

$621.9 .011-97$

\title{
$\mathrm{Ca}$ 快削鋼中の酸化物系介在物融点之切削温度の 関係についで
}

\author{
伊藤哲 朗** 高橋徹 夫*** \\ 木 村 篤 良*** 野 清 市***
}

\section{Relation between Cutting Temperature and Melting Point of \\ Oxide Inclusion in Calcium Bearing Free-Machining Steels}

\author{
Tetsurô Itô, Tetsuo Takahashi, \\ Atsuyoshi Kimura and Kiyoichi Yamano
}

\section{Synopsis}

Melting various kinds of calcium bearing free-machining steel whose oxide inclusions are different respectively, an investigation was made about the relation between the melting point of oxide inclusion and the cutting temperature that exerts P10 grade cemented carbide tool life.

1. The composition of oxide inclusion is affected by deoxidizer such as CaSi, $\mathrm{Al}, \mathrm{FeSi}$ etc. and it gives influence to the melting point of oxide inclusion.

2. The tool life will be improved if the ratio between the melting point of oxide inclusion and the cutting temperature is adjusted to about 1.7 . In this case, the "Belag" grows much.

3. Comparing $\mathrm{HMn}-\mathrm{S} 20 \mathrm{C}$ and $\mathrm{S} 45 \mathrm{C}$ with $\mathrm{S} 20 \mathrm{C}$ the cutting temperature is higher and accordingly the melting point of oxide inclusion is to be raised so as to meet the rising degree of the cutting temperature.

\section{1. 緒言}

$\mathrm{Ca}$ 快削銀は超硬工具，とくに TiCを含む超硬工具 で切削したとき，工具寿命が長くなるという特改をす っている。この原因として， $\mathrm{Ca}$ 快削錼中の酸化物系 介在物か沏削時の温度，压力により工具一切くず界面 で軟化あるいは溶融して工具に付着し，この付着物層 (ドイッ語で Belag と呼ぶ) か工具形成元素の切く ず中への拡散を防ぎ工具摩耗を㧕制すると考学られて

昭和 47 年10月28日受付

*日本鉄鋼協会第84回講演大会（昭47年秋）で発表

**大同製鎆蚮研究開発本部中央研究所, 工博

***大同製鋢侏研究開発本部中央研究所
(る1) -8)。

しかし Ca 快削錇といっても脱酸に用いる Ca 合金 の種類，使用法，他の脱酸剤との併用によって鋼中の 介在物組成, 形態は容易に変化するものであり, 鋼種 によっても大きく様子が異なってくる。そこでBelag 生成を最す望ましい状態にし最良の被削性を得るに は，銅中の酸化物系介在物を鋼種および切削条件に適 合した組成に調整することが大切とされているい。

本報では，Belag 生成に対して依存度の高いCa快 削鋼中の酸化物系介在物融点と，切削時の平均切削温 度との関係について C，Mnの異なった 3 䤡種につい て検討した。 
2. 实 験 方 法

\section{1 供試材の製造方法と化学成分}

供試材は， S 20Cと $\mathrm{Mn}$ 含有量を $1.4 \%$ 高めた
HMn-S 20C およびS 45Cを基本成分としたるのを， $2 \mathrm{t}$ アーク炉で溶解したのち, 下注造塊で $1.3 \mathrm{t}$ 鋼塊 にした。Table 1 に供試材の脱酸方法, 化学成分, 焼 ならしかたさを示す。

Table 1. Chemical composition, hardness and conditions of heat treatment of steels tested.

\begin{tabular}{|c|c|c|c|c|c|c|c|c|c|c|c|c|}
\hline \multirow{2}{*}{$\begin{array}{l}\text { Steel } \\
\text { grade }\end{array}$} & \multirow{2}{*}{$\begin{array}{c}\text { Speci- } \\
\text { men } \\
\text { No. }\end{array}$} & \multirow{2}{*}{$\begin{array}{c}\text { Deoxida- } \\
\text { tion }\end{array}$} & \multicolumn{8}{|c|}{ Chemical composition (wt \%) } & \multirow{2}{*}{$\begin{array}{r}\text { Hard - } \\
\text { ness } \\
\left(\mathrm{H}_{\mathrm{B}}\right)\end{array}$} & \multirow{2}{*}{$\begin{array}{l}\text { Heat } \\
\text { treat- } \\
\text { ment }\end{array}$} \\
\hline & & & $\mathrm{C}$ & Si & $\mathrm{Mn}$ & $\mathbf{P}$ & S & SAl & $\mathrm{Ca}$ & $\mathrm{O}$ & & \\
\hline \multirow{6}{*}{$\mathrm{S} 20 \mathrm{C}$} & A 1 & $\mathrm{FeSi}+\mathrm{Al}$ & 0.19 & 0.25 & 0.70 & 0.022 & 0.022 & 0.023 & $<0.001$ & 0.006 & 144 & \multirow{6}{*}{$\begin{array}{r}900^{\circ} \mathrm{C} \\
\times 2 \mathrm{hr} \\
\mathrm{AC} \mathbb{N}\end{array}$} \\
\hline & A 2 & $\mathrm{CaSi}+\mathrm{Al}$ & 0.19 & 0.25 & 0.61 & 0.016 & 0.028 & 0.004 & 0.002 & 0.011 & 145 & \\
\hline & A 3 & $\mathrm{CaSi}+\mathrm{FeSi}$ & 0.19 & 0.24 & 0.62 & 0.020 & 0.030 & 0.003 & 0.002 & 0.010 & 146 & \\
\hline & A 4 & $\mathrm{CaSi}+\mathrm{FeSi}$ & 0.20 & 0.27 & 0.58 & 0.018 & 0.015 & 0.002 & 0.002 & 0.010 & 146 & \\
\hline & A 5 & $\mathrm{CaSi}+\mathrm{FeSi}$ & 0.20 & 0.17 & 0.61 & 0.012 & 0.017 & 0.001 & 0.001 & 0.011 & 147 & \\
\hline & A 6 & $\mathrm{CaSi}+\mathrm{FeSi}$ & 0.21 & 0.27 & 0.69 & 0.019 & 0.018 & $<0.001$ & 0.001 & 0.011 & 146 & \\
\hline \multirow{6}{*}{$\begin{array}{l}\mathrm{HMn} \text { - } \\
\text { S20C }\end{array}$} & B 1 & $\mathrm{FeSi}+\mathrm{Al}$ & 0.17 & 0.34 & 1.41 & 0.015 & 0.018 & 0.022 & $<0.001$ & 0.005 & 156 & \multirow{6}{*}{$\begin{array}{l}900^{\circ} \mathrm{C} \\
\times 2 \mathrm{hr} \\
\mathrm{AC} \otimes\end{array}$} \\
\hline & B 2 & $\mathrm{CaSi}+\mathrm{Al}$ & 0.18 & 0.33 & 1.42 & 0.025 & 0.024 & 0.008 & 0.001 & 0.006 & 158 & \\
\hline & B 3 & $\mathrm{CaSi}+\mathrm{FeSi}$ & 0.19 & 0.28 & 1.44 & 0.021 & 0.029 & 0.004 & 0.002 & 0.009 & 160 & \\
\hline & B 4 & $\mathrm{CaSi}+\mathrm{FeSi}$ & 0.19 & 0.31 & 1.35 & 0.020 & 0.028 & 0.002 & 0.002 & 0.008 & 154 & \\
\hline & B 5 & $\mathrm{CaSi}+\mathrm{FeSi}$ & 0.20 & 0.32 & 1.48 & 0.020 & 0.026 & 0.001 & 0.002 & 0.011 & 160 & \\
\hline & B 6 & $\mathrm{CaSi}+\mathrm{FeSi}$ & 0.17 & 0.29 & 1.35 & 0.023 & 0.026 & 0.001 & 0.001 & 0.009 & 157 & \\
\hline \multirow{7}{*}{ S 45C } & C 1 & $\mathrm{FeSi}+\mathrm{Al}$ & 0.46 & 0.27 & 0.67 & 0.018 & 0.022 & 0.025 & $<0.001$ & 0.004 & 192 & \multirow{7}{*}{$\begin{array}{l}850^{\circ} \mathrm{C} \\
\times 2 \mathrm{hr} \\
\mathrm{AC}(\mathbb{8}\end{array}$} \\
\hline & C 2 & $\mathrm{CaSi}+\mathrm{Al}$ & 0.47 & 0.31 & 0.72 & 0.018 & 0.022 & 0.015 & 0.004 & 0.007 & 205 & \\
\hline & C 3 & $\mathrm{CaSi}+\mathrm{Al}$ & 0.48 & 0.23 & 0.74 & 0.021 & 0.022 & 0.008 & 0.002 & 0.007 & 203 & \\
\hline & C 4 & $\mathrm{CaSi}+\mathrm{FeSi}$ & 0.44 & 0.26 & 0.69 & 0.016 & 0.019 & 0.006 & 0.003 & 0.006 & 193 & \\
\hline & C 5 & $\mathrm{CaSi}+\mathrm{FeSi}$ & 0.44 & 0.27 & 0.66 & 0.023 & 0.015 & 0.004 & 0.004 & 0.010 & 193 & \\
\hline & C 6 & $\mathrm{CaSi}+\mathrm{FeSi}$ & 0.46 & 0.25 & 0.67 & 0.016 & 0.012 & 0.004 & 0.003 & 0.008 & 195 & \\
\hline & C 7 & $\mathrm{CaSi}+\mathrm{FeSi}$ & 0.48 & 0.23 & 0.63 & 0.016 & 0.019 & 0.002 & 0.001 & 0.008 & 200 & \\
\hline
\end{tabular}

$\mathrm{A}-1, \mathrm{~B}-1, \mathrm{C}-1$ は FeSi ( J I S 2 号) と金属 Alで脱酸した基本鋼である。他のシリーズは CaSiに $\mathrm{Al}$ なし FeSiを適宜組み合せて脱酸処理し，酸化物 系介在物を高融点から低融点の種々異なる組成に調整 した。

$\mathrm{Ca}$ 快削鋸中に含まれる $\mathrm{Ca}$ 量は，鎙種によっても 差が認められるが0.001〜0.004\%の範囲にあり, 基本 鋼は $0.001 \%$ 以下である。酸素量は基本銅に比較し, $\mathrm{Ca}$ 快削鋼は若干高くなっている。

試験材は，鋼塊を $100 \phi \mathrm{mm}$ に熱間圧延したのち Table 1 に示す条件で烍ならし処理した。

\section{2 非金属介在物の測定}

供試材中の酸化物系介在物組成を調べるため下記の 方法で測定した。また同一試料で顕微鏡観察を行なっ t:

(1) Br-メタノール法による介在物分析

$\mathrm{S} 20 \mathrm{C}$ 扰よびHMn-S20Cの Ca 快削鋼は，Br-メタ ノール法と呼ぶ抽出分傩分析法により平均組成を求め た5)。

(2) E P MAによる介在物分析

Brーメタノール法による分析が困難な S 45C 系につ いては, EPMA 法によった。この分析法の場合に 
は，同一試料内での介在物間の組成の差のバラッキが かなりあるため4，測定数は少なくとも5 点以上と し，著しくバラッキを示するのを除いてその平均值を とった。

\section{3 酸化物系介在物の融点測定}

Fig. 1 亿示すごとく $\mathrm{Ca}$ 快削鋼中の酸化物系介在 物を，S.Al で相関をとってみると鋼種間によって多 少の差も認められるが，S.A1 0.006\%以下になると，

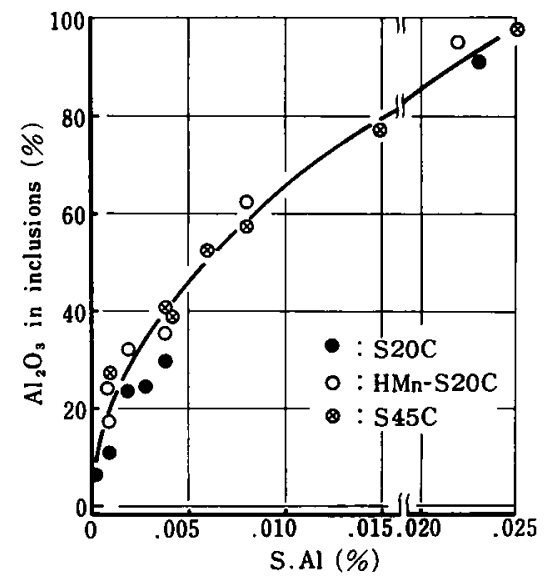

$\mathrm{SiO}_{2}-\mathrm{Al}_{2} \mathrm{O}_{3}-\mathrm{CaO}$ の 3 元系に $\mathrm{MnO}$ が入った 4 元系 の複合酸化物となる。この $\mathrm{SiO}_{2}-\mathrm{Al}_{2} \mathrm{O}_{3}-\mathrm{CaO}-\mathrm{MnO}$ 系の 4 元系酸化物の融点は，現在公表されている 3 元 系状態図から求めることがむずかしいため, 試料中の 酸化物系介在物平均組成之同一組成となるよう合成酸 化物を配合し， $20 \mathrm{~kg}$ 高周波誘導炉で溶融均一化したの ち粉砕し，高温顕微鏡および三角錐法で融点を測定し た。

Fig. 1. Relation between soluble $\mathrm{Al} \%$ in steels and $\mathrm{Al}_{2} \mathrm{O}_{3}, \mathrm{SiO}_{2}$ and $\mathrm{MnO} \%$ in oxide inclusions.

\section{4 超硬工具による切削試験}

切削試験は無段变速機を内蔵した大隈鉄工製 $15 \mathrm{P}$ 旋 盤で，長手旋削を行ない切削温度湘定と工具寿命につ いて試験した。切削条件は下記のとおりである。

工具材種：超硬工具 P10種（スローアウエイチ $\left.\because フ^{\prime}\right)$

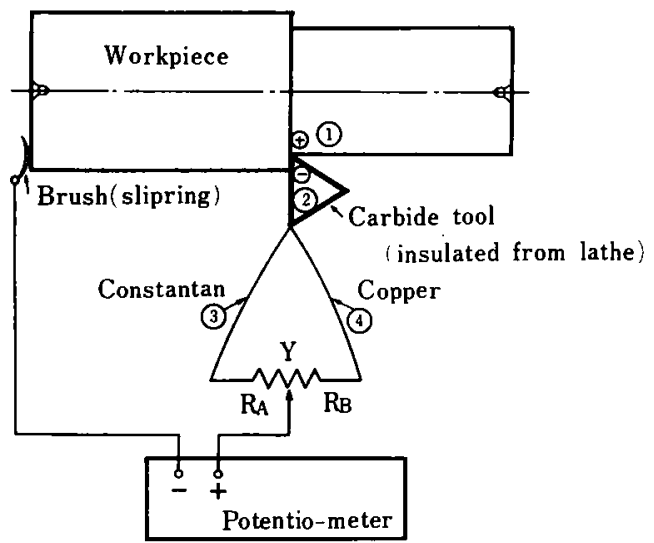

工具形状： $-5,-5,5,5,30,0,0.4$

切削速度： $150,200,250 \mathrm{~m} / \mathrm{min}$

送り : $0.2 \mathrm{~mm} / \mathrm{rev}$

切込み : $2.0 \mathrm{~mm}$

切削油 : 乾切削

切削温度の測定は Fig.2に示すごとく，工具と被削

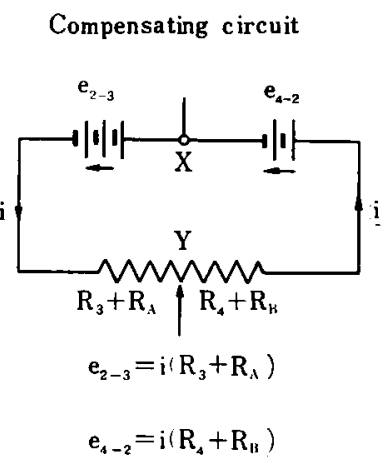

Fig. 2. Method of measuring cutting temperature with compensating circuit. 
材の熱軍対法を用い温度補償には，K. J. Trigger の 補償回路法によっだ'。この場合平均切削温度として 測定される。

\section{3. 英験結果および考察}

\section{1 非金局の介在物組成，形態および融点}

Photo. 1 は, Leitz 高温顕微鏡によるA-4 試料 の実測例を，Table 2 はBrーメタノール法扰よび E PMAで求めた酸化物系介在物の平均組成と，合成

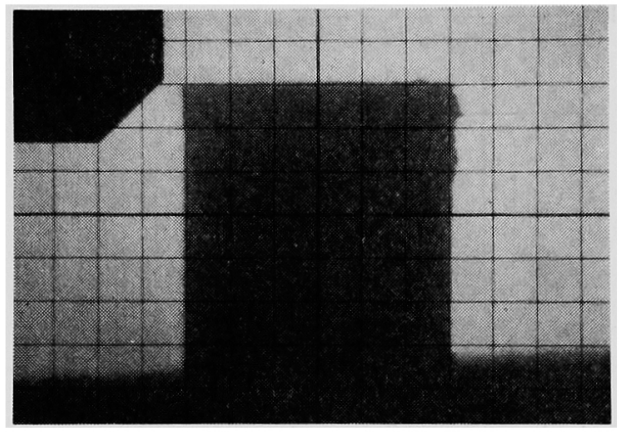

Room temperature $\left(20^{\circ} \mathrm{C}\right)$

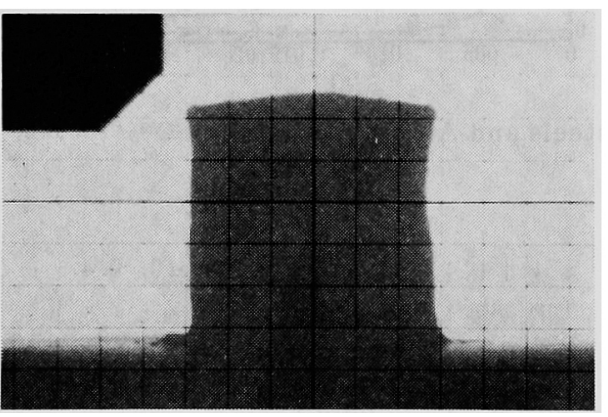

Begining of softening $\left(1220^{\circ} \mathrm{C}\right)$

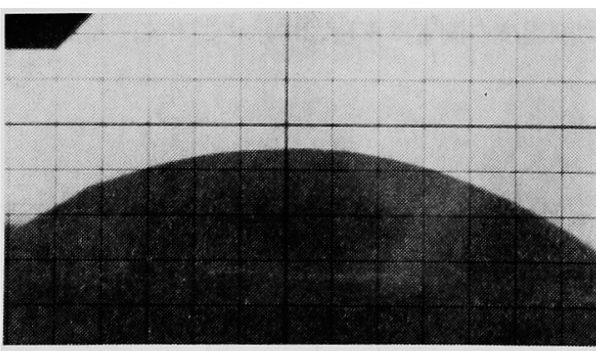

Melting point $\left(1310^{\circ} \mathrm{C}\right)$

Oxide composition (A-4) \%

\begin{tabular}{|c|c|c|c|}
\hline $\mathrm{SiO}_{2}$ & $\mathrm{Al}_{2} \mathrm{O}_{8}$ & $\mathrm{CaO}$ & $\mathrm{MnO}$ \\
\hline 48 & 23 & 17 & 12 \\
\hline
\end{tabular}

Photo. 1. The measurement of melting point of oxide compounds with Leitz hot microscope.

酸化物で測定した融点を示す。

Photo. 1 の試料は直径 $3 \mathrm{~mm}$, 高さ $3 \mathrm{~mm}$ の柱
状にプレス成形したすのを白金板台上に設置し，抵抗

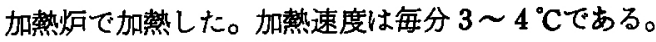

Table 2. Average of oxide composition in steels and melting point of compounded oxide.

\begin{tabular}{|c|c|c|c|c|c|}
\hline \multirow{2}{*}{$\underset{\text { mon }}{\text { Speci- }}$} & \multicolumn{4}{|c|}{$\begin{array}{c}\text { Average of oxide } \\
\text { composition }\end{array}$} & \multirow{2}{*}{$\begin{array}{l}\text { M. P } \\
\left({ }^{\circ} \mathrm{C}\right)\end{array}$} \\
\hline & $\mathrm{SiO}_{2}$ & $\mathrm{Al}_{2} \mathrm{O}_{8}$ & $\mathrm{CaO}$ & $\mathrm{MnO}$ & \\
\hline A 1 & $7^{\%}$ & $91^{\% / 6}$ & $2^{\%}$ & 0 & 1950 \\
\hline A 2 & 47 & 30 & 15 & 8 & 1420 \\
\hline A 3 & 51 & 24 & 17 & 10 & 1350 \\
\hline A 4 & 48 & 23 & 17 & 12 & 1300 \\
\hline A 5 & 45 & 10 & 10 & 35 & 1160 \\
\hline A 6 & 46 & 6 & 6 & 42 & 1120 \\
\hline
\end{tabular}

\begin{tabular}{|c|c|c|c|c|c|}
\hline \multirow{2}{*}{$\begin{array}{c}\text { Speci- } \\
\text { men } \\
\text { No. }\end{array}$} & \multicolumn{4}{|c|}{$\begin{array}{c}\text { Average of oxide } \\
\text { composition }\end{array}$} & \multirow{2}{*}{$\begin{array}{l}\text { M. P } \\
\left({ }^{\circ} \mathrm{C}\right)\end{array}$} \\
\hline & $\mathrm{SiO}_{2}$ & $\mathrm{Al}_{2} \mathrm{O}_{3}$ & $\mathrm{CaO}$ & $\mathrm{MnO}$ & \\
\hline B 1 & 5 & $95^{\%}$ & $0^{7 / 1}$ & $0^{0 / 1}$ & 2000 \\
\hline B 2 & 23 & 62 & 13 & 2 & 1700 \\
\hline B 3 & 45 & 35 & 11 & 9 & 1440 \\
\hline B 4 & 47 & 32 & 9 & 12 & 1400 \\
\hline B 5 & 42 & 17 & 19 & 22 & 1180 \\
\hline B 6 & 45 & 24 & 6 & 25 & 1230 \\
\hline
\end{tabular}

\begin{tabular}{|c|c|c|c|c|c|}
\hline \multirow{2}{*}{$\begin{array}{c}\text { Speci- } \\
\text { men } \\
\text { No. }\end{array}$} & \multicolumn{4}{|c|}{$\begin{array}{c}\text { Average of oxide } \\
\text { composition }\end{array}$} & \multirow{2}{*}{$\begin{array}{l}\text { M. P } \\
\left({ }^{\circ} \mathrm{C}\right)\end{array}$} \\
\hline & $\mathrm{SiO}_{2}$ & $\mathrm{Al}_{2} \mathrm{O}_{3}$ & $\mathrm{CaO}$ & $\mathrm{MnO}$ & \\
\hline C 1 & $2^{\%}$ & 97 & $1 \%$ & $0^{\% / 2}$ & 2000 \\
\hline C 2 & 6 & 77 & 17 & 0 & * 1770 \\
\hline C 3 & 18 & 57 & 25 & 0 & 1630 \\
\hline C 4 & 22 & 52 & 24 & 2 & 1590 \\
\hline C 5 & 27 & 40 & 33 & 2 & 1470 \\
\hline C 6 & 28 & 39 & 32 & 1 & 1450 \\
\hline C 7 & 52 & 25 & 9 & 13 & 1360 \\
\hline
\end{tabular}

$1220^{\circ} \mathrm{C}$ で軟化が始まり， $1310^{\circ} \mathrm{C} て ゙$ 完全に溶骶したため 融点とした。一方, 同一試料をゼーゲルコーンと比較 試験し䛿点をチェックしたところ，両者はかなりよく 一致した。な括※は，Alの高いCa快削鋼および基本 鋼の高融点酸化物は，測定がむずかしかったので文献 報告されている状態図を活用しだ。 
$\mathrm{FeSi}$ と金属 $\mathrm{Al}$ で脱酸した基本鋼の酸化物骼点 は1950 $2000^{\circ} \mathrm{C}$ 高い。 $\mathrm{Ca}$ 快削鋼の酸化物融点は, $\mathrm{CaO}$ 量の多少によって若干差があるるのの, $\mathrm{Al}_{2} \mathrm{O}_{3}$ の減少と $\mathrm{SiO}_{2}$ および $\mathrm{MnO}$ の増加ととすに低融点側 に移行する。

Photo. 2 は, 光学䫓微鏡により観察した酸化物系

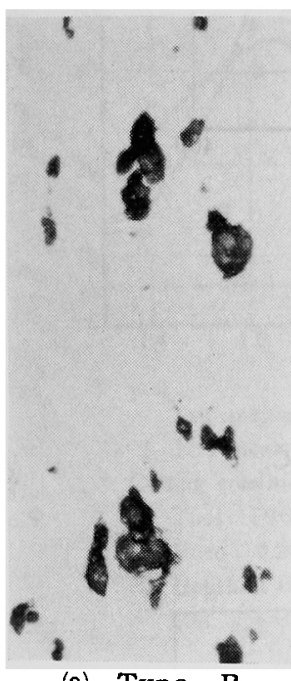

(a) Type

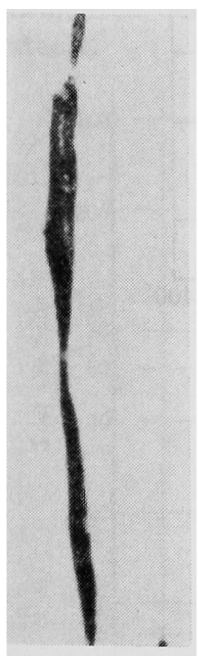

(c) Type $\mathrm{A}_{2}$

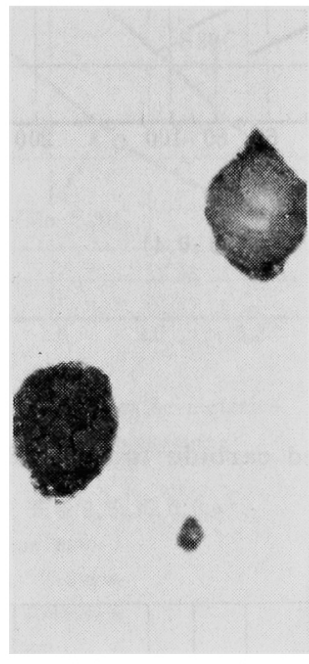

(b) Type C
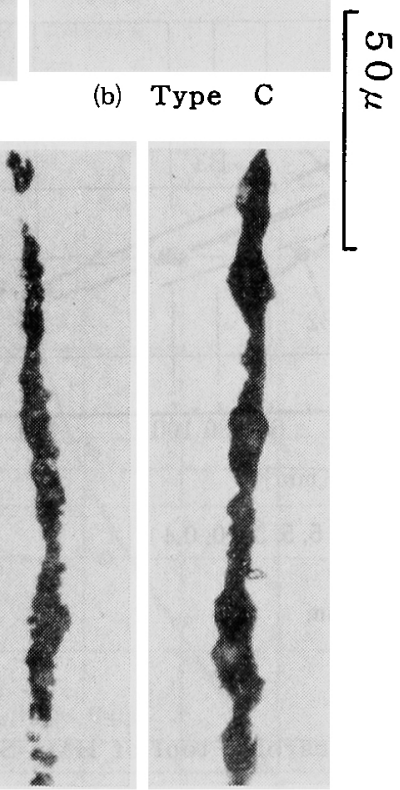

(d) Type $\mathrm{A}_{2}^{\prime}$

Photo. 2. Microphotographs of various types of oxide inclusions.

介在物の代表例である。Photo. 2（a）は，FeSi+ $\mathrm{A} 1$ 脱酸した基本鋼（A-1，B-1，C-1）でみられた $\mathrm{Al}_{2} \mathrm{O}_{8}$ リッチなストリンガ状の $\mathrm{B}$ 系介在物である。 Photo. 2 (b) はC 系の介在物で鋼中のAl，Ca が高 い試料たとえば， B-2，C-2，C-3 で多く認めら れた。この介在物は軟化開始点および融点が熱間圧延

温度より高いため変形しない。Photo. 2（c）は熱間 压延でなめらかに変形した $\mathrm{A}_{2}$ 系介在物で, 融点が13 $50^{\circ} \mathrm{C}$ 以下の試料で欢られた。Photo. 2 (d) は $\mathrm{A}_{2}$ 系 介在物よりもやや融点が高い試料(たとえば，A-2， B-3など）でみられた介在物で，熱間圧延で変形す るるのの周辺にでこ舌このある $\mathrm{A}_{2}^{\prime}$ 系介在物である。

\section{2 切削瑥度の測定結果}

Fig.3 は 3 鋼種について, $\mathrm{H}_{\mathrm{B}}$ かたさと平均切削温

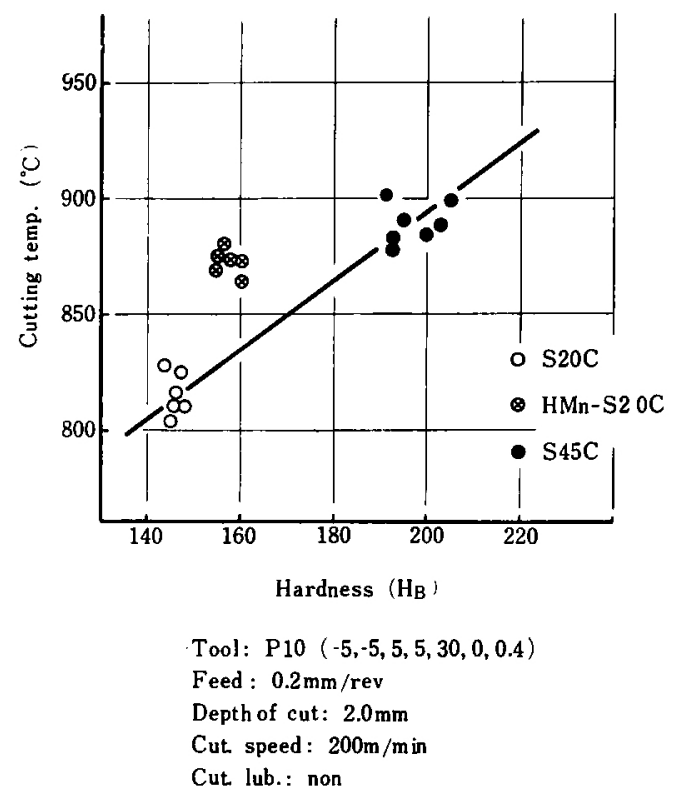

Fig. 3. Relation between hardness and mean cutting temp. in the $\mathrm{S} 20 \mathrm{C}, \mathrm{HMn}-\mathrm{S} 20 \mathrm{C}$ and S45C steels.

度との関傒を切削速度 $200 \mathrm{~m} / \mathrm{min}$ について示したもの で，C含有量のみが異なる S $20 \mathrm{C} と \mathrm{~S} 45 \mathrm{C}$ を直線で結 ぶと, Mnの高い HMn-S20C は S20Cに比べ, $\mathrm{H}_{\mathrm{B}}$ かたさの上昇以上に切削温度が高くなった。これは Mn を高めたことによる靶性の向上,パーライト組織 の差などが原因として考えられる。

\section{3 工具寿命試験結果}

Fig.4，5は，S20Cおよび HMn-S20Cについて 工具寿命判定基準をフランク摩耗幅 $\left(\mathrm{V}_{\mathrm{B}}\right) 0.20 \mathrm{~mm}$ と したときの工具寿命曲線を示す。ここで $\mathrm{V}_{\mathrm{B}}$ を基準と したのは，Ca 快削鋼の場合すくい面に Belag が付 着して摩耗の進行が抑制され，すくい面摩耗よりるフ ランク摩耗の方が，より速く進行するためである。

Fig. 4 の S20C についてみると, 切削速度 200 $\mathrm{m} / \mathrm{min}$ における工具寿命は基本鋼の A- 1 に比較し 


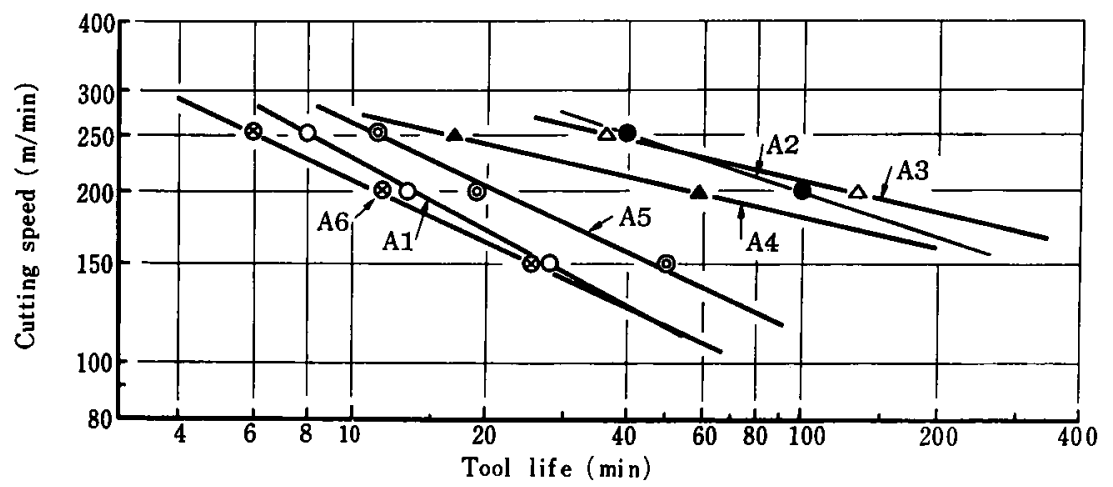

Tool : P10 $(-5,-5,5,5,30,0,0.4)$

Feed : $0.20 \mathrm{~mm} / \mathrm{rev}$

Depth of cut : $2.0 \mathrm{~mm}$

Cutting lub. : non

$$
V_{B}=0.20 \mathrm{~mm}
$$

Fig. 4. Tool life curves with cemented carbide tool of S20C.

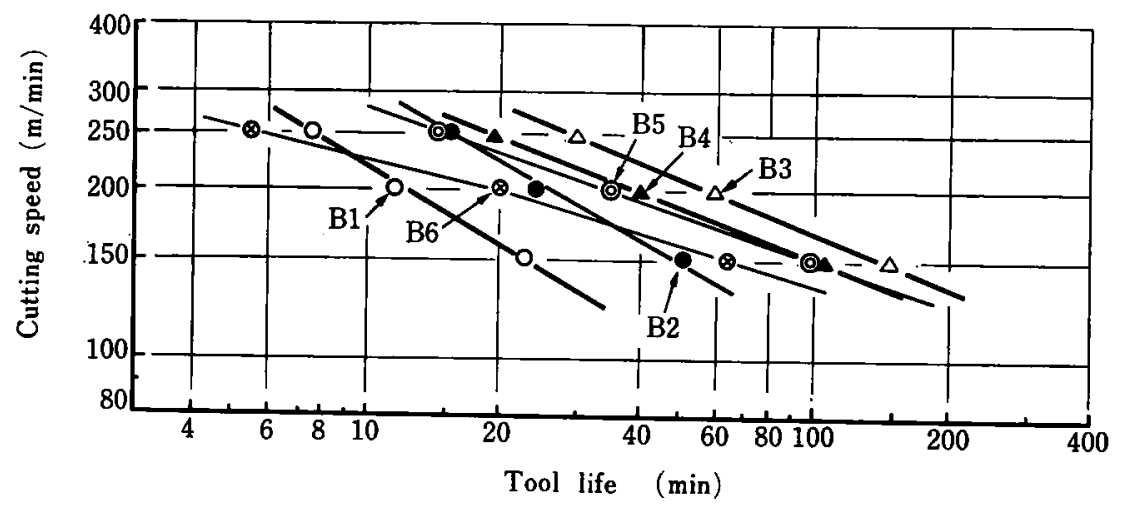

Tool : P10 $(-5,-5,5,5,30,0,0.4)$

Feed : $0.20 \mathrm{~mm} / \mathrm{rev}$

Depth of cut: $2.0 \mathrm{~mm}$

Cutting lub.: non

$\mathrm{V}_{\mathrm{B}}=0.20 \mathrm{~mm}$

Fig. 5. Tool life curves with cemented carbide tool of HMn-S20C.

て, A-2, A-3，A-4 のCa快削鋼の上 5 に酸化物 采介在物融点を $1300 〜 1420^{\circ} \mathrm{C}$ 調整することにより，

$5 \sim 10$ 倍工具寿命が向上する。しかも V-T 曲楾の傾 斜角が小さいため，低速になるほど基本鋼との寿命差 は大きくなる。一方介在物融点を著しく低めた A-5， A-6 試験材は，基本銅並みの工具寿命にとどまっ た。この理由については後述する。

Fig. 5 のHMn-S20C についてみると，その切削 速度 $200 \mathrm{~m} / \mathrm{min}$ に捕ける工具寿命は基本鋼の B- 1 K
比較してB-3，B-4のよ5に，介在物融点を1400〜 $1440^{\circ} \mathrm{C}$ 調整すると， $4 \sim 6$ 倍工具寿命が向上する。 介在物融点を $1180 \sim 1230^{\circ} \mathrm{C}$ に低めた B- $5 ， \mathrm{~B}-6$ 試駼 材については，基本鋼の $2 \sim 3$ 倍の工具寿命にとどま ot。

\section{4 工具寿命におよぼす介在物戨点と切削温度と} の関係

今まで求めてきた酸化物系介在物融点と平妇切削温 度との比, $\mathrm{T}_{\mathrm{MP}} / \mathrm{T}_{\mathrm{c}}$ と工具寿命の関㐿を切削速度 200 
m/minについて整理したものが，Fig.6, 7 である。

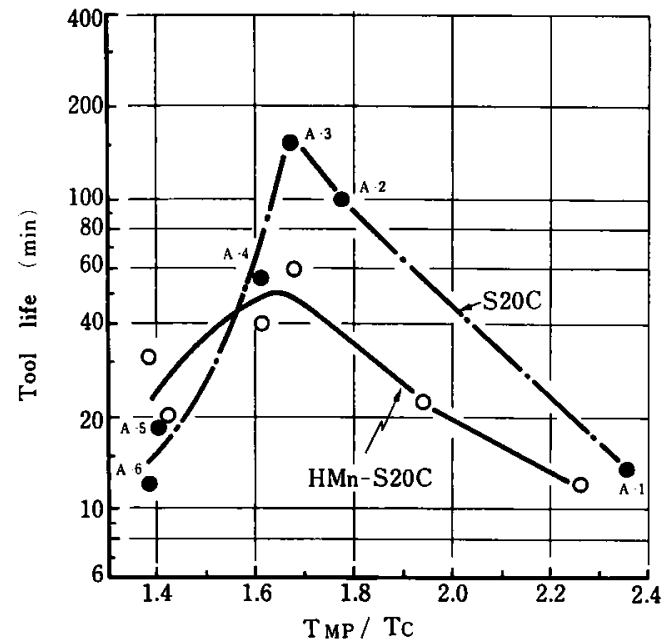

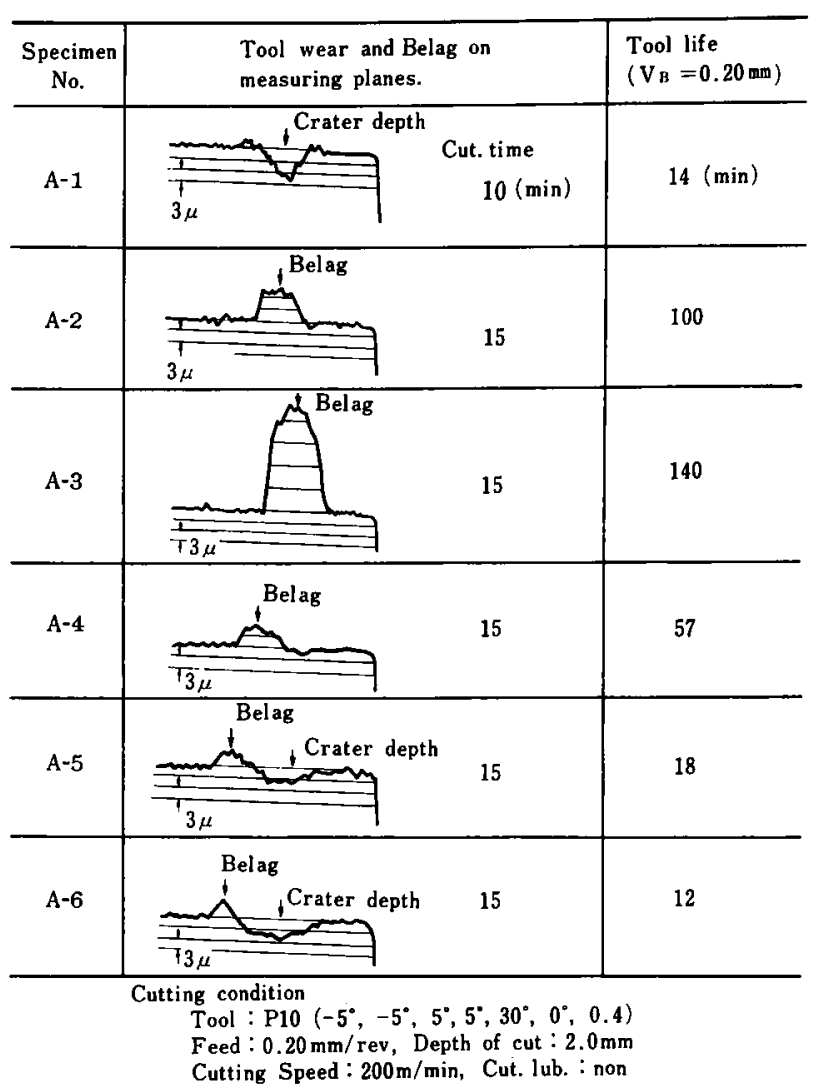
cemented carbide tool. (S20C and HMn-S20C steels)

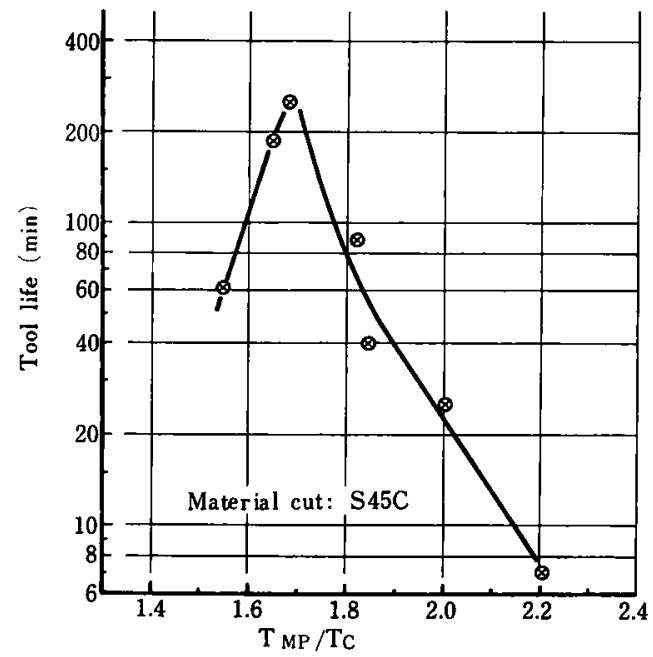

$T_{M P}$ : melting point of oxide inclusion

$T_{C}$ : mean cutting temperature

Cutting condition

Tool : P10 $(-5,-5,5,5,30,0,0.4)$

Feed : $0.2 \mathrm{~mm} / \mathrm{rev}$

Depth of cut $: 2.0 \mathrm{~mm}$

Cut. speed $: 200 \mathrm{~m} / \mathrm{min}$ $\mathrm{V}_{\mathrm{B}}=0.20 \mathrm{~mm}$

Fig. 7. Effect of $T_{M P} / T_{C}$ on the tool life of cemented carbide tool. ( $\mathrm{S} 45 \mathrm{C}$ steels)

Fig. 8. Tool wear and Belag on measuring planes. (S20C steels)

Fig. 6 についてみると， S20C および HMn-S20C とも工具寿命のもっともすぐれたところは， $\mathrm{T}_{\mathrm{MP}} / \mathrm{T}_{\mathrm{C}}$ $=1.7$ 付近に存在し, Fig. 7 のS $45 \mathrm{C}$ に関しても $\mathrm{T}_{\mathrm{MP}} / \mathrm{T}_{\mathrm{C}}=1.7$ の狭い範囲に工具寿命のピークがある ことが判った。そして Fig. 8は S20Cのすくい面の 状態を示したすのであるが， $\mathrm{T}_{\mathrm{MP}} / \mathrm{T}_{\mathrm{C}}=1.7$ 付近の A-2，A-3 試験材はもっとも Belag の付着量が多 く，基本鋼の $\mathrm{A}-1$ および介在物融点を著しく低めた A-5，A-6 試験材は Belag は認められずクレータ 摩耗が発生している。これらの傾向はHMn-S20C, S 45Cにも認められた。ここで鋼種が異なると工具寿 命はともに $\mathrm{T}_{\mathrm{MP}} / \mathrm{T}_{\mathrm{C}}=1.7$ でもっとも良好であるが， 曲線の傾向が若干異なってくることがわかる。これは 同じ融点をるつ $\mathrm{Ca}$ 系介在物を鋼中に含有していても 鋼種が異なれば切削温度も異なり工具寿命曲線のこう 配も異なるため, 工具寿命比は切削速度すなわち切削 温度が変化すれば一定とならない。この結果, 鋼種に よって $\mathrm{T}_{\mathrm{MP}} / \mathrm{T}_{\mathrm{c}}$ と工具寿命の曲線の傾向は異なるわけ であるが，主なる原因は各鋼種マトリックスのせん断 応力およびせん断ひずみのちがいにあると考えられ， 単にかたさたけに起因していないことは Fig. 3 から 
あ明白である。

この実験結果から，切削温度に対して酸化物系介在 物融点が $2000^{\circ} \mathrm{C}$ 高温となっている基本鋼では，当然 Belag は生成せず，介在物は工具に対してすべてつ ブレーシブに作用するとともに，工具形成元素は切く ず中に㹡散され，工具摩耗が進行する。

Ca 快削鋼といえども酸化物系介在物骶点によって 工具寿命に差か認められるのは，つぎの理由が考劣ら れる。鋼中に找ける介在物組成はE PMA測定などか ら一定ではなく，かなりの䈥囲にわたっていることが 普通である。したがって，切削温度（速度）に応して 介在物は選択されてBelagkなるすのと考光るとで， $\mathrm{T}_{\mathrm{MP}} / \mathrm{T}_{\mathrm{C}}=1.7$ 付近の試験片では Belag の付着量か;多 く，工具寿命がもっともよいことからみて，工具と接 触した介在物の大部分が Belag として付着し, 工具 摩耗を著しく抑制する。一方 $\mathrm{T}_{\mathrm{MP}} / \mathrm{T}_{\mathrm{C}}=1.7$ よりもや や数值の高い $\mathrm{Ca}$ 快削鋼では，全体として介在物は高 融点側にあるため，本来はフプレーシブと作用する か，中には低融点の介在物も存在するため，それか Belag として付着し工具摩耗を抑制する。この場合 Belag の付着は完全でないため, 工具寿命はいく ぶん低下する。他方 $\mathrm{T}_{\mathrm{MP}} / \mathrm{T}_{\mathrm{C}}=1.7$ よりるやや数值の 低いCa 快削銅では，大部分の介在物は，切削時の温 度，圧力に耐えず工具すくい面後方に押し流されてし ま5が，一部存在する比較的高融点の介在物がBelag として働き，工具摩耗の進行を若干抑制するため，

Fig. 6，7の上5な工具寿创を示した。そして $\mathrm{MnO}$ を多量に含む著しい低融点の酸化物系介在物は，すべ て工具すくい面後方に押し流されるため，工具摩耗が 著しく進行し，基本鋼並みの工具寿命にとどまったも のと考えられる。

Fig. 6，7の結果から，3 鋼種の切削速度 $200 \mathrm{~m} /$ minにおけける工具寿命をすっともすぐれたものにする 酸化物系介在物の融点は， S $48 \mathrm{C} \mathrm{Ca}$ 快削鍋では約 $1450^{\circ} \mathrm{C}$ である。 S $20 \mathrm{C}$ 系は約 $1350^{\circ} \mathrm{C} て ゙ あ り ， \mathrm{Mnt1.4}$

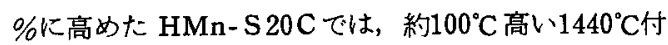
近に調整すればよいことがわかった。

なお，本実験に示した切削温度は被削材と工具の熱 電対法による平均切削温度であり実際には Fig. $9^{93}$ に示すよ 5 な温度分布があり, 最高切削温度域が存在 する。工具寿命に直接影響するのはこの最高切削温度 であり K.J. Trigger ${ }^{101}$, E.G. Luewen ${ }^{11}$ らによれ ば最高切削温度は平均切削温度の1.3〜1.5倍であると されている。したがって今回の最高切削温度は $\mathrm{S} 20 \mathrm{C}$ で $1200^{\circ} \mathrm{C}, \mathrm{HMn}-\mathrm{S} 20 \mathrm{C}$ で $1270^{\circ} \mathrm{C}, \mathrm{S} 45 \mathrm{C}$ で $1300^{\circ} \mathrm{C}$ と いちことになるか，これらの温度は切削圧力の影響を

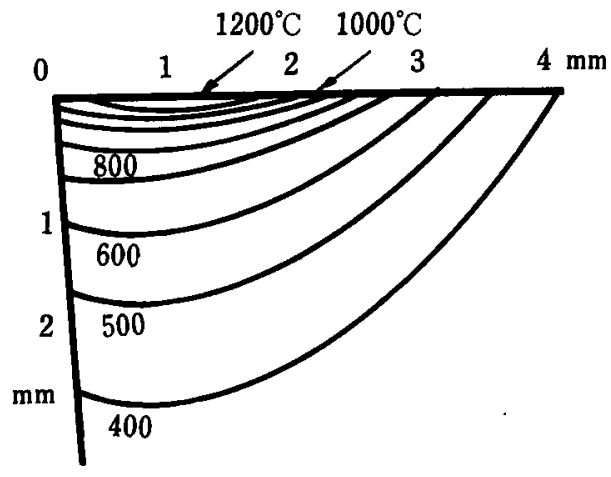

Material cut : $30 \mathrm{Mn} 4$

Tool : cemented carbide P10

Rake angle : $0^{\circ}$

Clearance angle $: 4^{\circ}$

Entering angle : $45^{\circ}$

Feed : $0.74 \mathrm{~mm} / \mathrm{rev}$

Cutting depth $: 3 \mathrm{~mm}$

Cutting speed $: 180 \mathrm{~m} / \mathrm{min}$

Fig. 9. Variations in temperature in a turning tool measured perpendicular to the cutting edge.

あ考党あわせればそれぞれの銅中 $\mathrm{Ca}$ 系介在物の軟化 温度と活涪一致する。このことから切削時の切刃部最 高温度か: $\mathrm{Ca}$ 采介在物の軟化温度と注㴗一致したとき Belag はもっと多く付着し工具寿命ももっとも良好と なるといえる。これを平均切削温度と $\mathrm{Ca}$ 系介在物の 溶融点の比であらわすと $1: 1.7$ となる。

4. 結

論

S 20C，Mnを 1.4\%に高めた HMn-S20C および S45Cについて，酸化物系介在物組成をか之，P10超 硬工具寿命におよ涪す介在物融点と切削温度との関保 を検討した。得られた結果を要約するとつぎのとおり である。

（1）Ca 快削鋼中の酸化物系介在物組成は $\mathrm{CaSi}$, $\mathrm{Al}, \mathrm{FeSi}$ などの脱酸刜の処理法によって変化し 介在物融点を左右する。高融点の介在物にするには $\mathrm{S} . \mathrm{Al}$ 高めて介在物中の $\mathrm{Al}_{2} \mathrm{O}_{3}$ を増し, $\mathrm{SiO}_{2}, \mathrm{MnO}$ を減ずればょく，低融点にするにはその逆の方法をと ればよい。

(2) 工具寿命をもっともすぐれたものにするには, 酸化物系介在物融点 $\left(\mathrm{T}_{\mathrm{MP}}\right)$ と切削温度 $\left(\mathrm{T}_{\mathrm{C}}\right)$ の比 を一定值に調整する必要がある。すなわち， $\mathrm{T}_{\mathrm{MP}} / \mathrm{T}_{\mathrm{C}}$ $=1.7$ 程度に介在物融点を調整すれば, Belag の付着 量は多く工具寿命はもっとも高められる。

(3) したがってS20Cに比較して切削温度の高くな る $\mathrm{HMn}-\mathrm{S} 20 \mathrm{C} ， \mathrm{~S} 45 \mathrm{C}$ は切削温度上昇飞見合うた 
け，酸化物系介在物融点を高めなければよりすぐれた 工具寿命が得られない。

これらの知見をもとに, $\mathrm{Ca}$ 快削鋼の鋼種抾大化お よび同一銅種内に打ける熱処理のちかいによるかたさ の影響がある場合にる適用化を図り，Ca 快削鋼全般 のレベルアップに寄与したいと考㝋ている。

終わりに本研究を行ならにあたり，終始ご指導，ご 協力を賜わった大同製鋼鿟研究開発本部中央研究所第 5 研究室長阿部山尚三氏, 柴田範嘉氏, 第 1 研究室研 究員柳田稔氏ならびに関保諸氏に深く感謝いたしま す。

\section{（女 献）}

1）奥島, 鳴潼:精密僟械，35（1962）2，28～34

2）加藤, 吉田:精機学会秋期講演会前刷, (1969),
$243 \sim 246$

3）鳴湆, 岩田注か:鉄と銅, 56 (1970) 3，391 401

4) 山田忹か:鉄と鋼, 57 (1971) 13，2111〜2127

5）椙山, 加藤にか：金属学会秋期講演会前刷, (1969), 199

6) K. J. Trigger: Trans. ASME., 80 (1958), 302

7) 伊藤，加藤ほか:電気製銅，43（1972） $2 ， 83$ 93

8) Phase Diagrams for Ceramists (1964)

9) K. J. Küsters: Industrie-Anzeiger. Essen. , 6 (1956), 1337 1340

10) K. J. Trigger, B. J. Chao: Trans. ASME., 73 (1951), 230

11) E.G.Luewen, M.C.Shaw: Trans. ASME., 74 (1952), 217

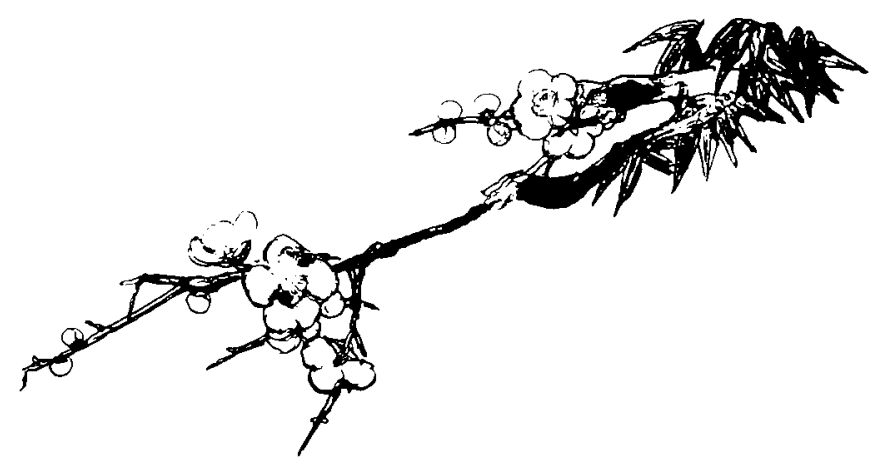

